\title{
AMINO ACID METABOLISM OF MALASSEZIA FURFUR
}

\author{
by ZENAB EL-GOTHAMY, M. D.
}

\begin{abstract}
SUMMARY. The mechanism responsible for the hypopigmentation which follows pityriasis versicolor (P.V.) infection has not yet been satisfactorily explained. This work was done in order to study the effect of Malassezia furfur on the decomposition or the utilization of the amino acid tyrosine in vitro. No effect could be noted, which points to the assumption that the effect of the causative fungus of P.V. on melanogenesis is most probably due to the blocking of melanine synthesis by one of the product of $M$. furfur metabolism without using tyrosine.
\end{abstract}

\section{Métabolisme des acides aminés chez (Malessezia Furfur).}

RÉSUMÉ. Le mécanisme responsable de l'hypopigmentation des lésions de Pityriasis versicolor n'a jamais été élucidé. L'hypothèse que cette hypopigmentation résulte d'une compétition dans l'utilisation de la tyrosine entre le champignon et les mélanocytes n'est pas confirmée par l'expérimentation de l'auteur : in vitro du moins, $M$. furfur ne métabolise pas cet acide aminé.

Pitiryasis versicolor (P.V.) is of world-wide distribution, particularly in tropical and subtropical countries (El-Hifnawi et al, 1971). It mostly brings about no functional disorders and what annoys the patient is the cosmetic appearance, especially the hypopigmentation that commonly resists treatment. The pathogenesis of the hypopigmentation in cases of P.V. has not yet been satisfactorily explained, although various, theories have been proposed to explain this phenomenon. From a previous study a suggestion was made, that this could be an interference with the process of melanin formation, with subsequent decrease of melanin granules in the keratinocytes (El-Gothamy et al., 1975). Ito and Tanaka (1972), in one of a series of investigations in the keratinolytic activities of pathogenic fungi, studied L-tyrosine metabolism by pathogenic fungi particularly those affecting the skin, but without reference to $M$. furfur. In this work the effect of P.V. on the decomposition or utilization of the amino acid tyrosine was studied.

\footnotetext{
* Département of dermatology, Faculty of Medicine, Ain Shams University, Cairo, Egypt.
} 


\section{Material and methods}

Twenty cases of P.V. were examined by direct microscopic examination using $10 \%$ potassium hydroxide for the presence of hyphal elements and group of spores of $M$. furfur. All cases were positive. Skin scraping from the 20 cases were cultured on Mycosol agar overlaid with a thin layer of sterile olive oil at both $25^{\circ} \mathrm{C}$ and $37^{\circ} \mathrm{C}$. Positive cultures were obtained in 15 cases only. The colonies consisted of a thin film, composed of a thickwalled spherical budding organism, 2, 5 to $5 \mu \mathrm{m}$ in diameter, very closely resembling the spherical elements of the spores that appear in direct microscopic examination. It resembles the organism described by Gordon (1951 a) named by him Pityrosporum orbiculare. An inoculum of this was transferred on a medium containing the amino acid tyrosine. This medium consisted of a suspension of $0.5 \mathrm{~g}$. tyrosine in $10 \mathrm{ml}$. distilled water, autoclaved and freshly sterilized nutrient agar $100 \mathrm{ml}$ (peptone $5 \mathrm{~g}$., beef extract $3 \mathrm{~g}$., agar $15 \mathrm{~g}$. dissolved in $1000 \mathrm{ml}$ of distilled water at $\mathrm{pH} 7.0)$. Both mixtures were cooled to about $50^{\circ} \mathrm{C}$, mixed together and a continuous stirring of the mixtures was kept on while pouring them in sterile Petri dishes. The cultures were checked daily for 14 days for the appearance of a clear zone around the fungal colonies. This clear zone results from the hydrolysis of tyrosine cristals and denotes utilization of the amino acid tyrosine (L. K. Georg, 1974).

\section{Results}

None of the cultures showed a clear zone around any of the colonies.

\section{Discussion}

The pathogenesis of hypopigmentation in P.V. is still not clear, although various theories have been proposed (Kistiakovsky, 1927) Lewis and Hopper, 1936, Hildick (Smith et al, 1964, Bears et al, Wilson and Plunket, 1970). In a previous study (El-Gothamy et al, 1975), DOPA reaction and Fontana stain showed a decrease of melanin pigment inside the melanocytes and keratinocytes in P. V. cases compared with unaffected skin from similar anatomical area in the same patient. This denotes some sort of disturbance in the process of a melanin formation in cases of P.V. In this work a trial was made in order to investigate the stage at which the process of melanogenesis is affected by P.V. As the causative organism of P.V. is still under discussion (Salkin and Gordon, under publication) newly prepared cultures from cases of P.V. were used in this work. No decomposition or utilization of the amino acid tyrosine could be obtained in all the cultures studied. Considering the process of melanogenesis which occurs entirely within the melanocytes, it involves the convertion of the colourless amino acid tyrosine into the brown-black polymer melanin and once melanin is formed, it is transformed from melanocytes into keratinocytes. From this we can deduce that the effect of P.V. on melanogenesis is most probably due to the blocking of melanine synthesis by one of the products of $M$. furfur metabolism which can interfere on this synthesis without using tyrosine. 


\section{REFERENCES}

Bears J. M., Gentles J. C., Mackenzie D. W. R. : In : testbook of Dermatology, Edited by Rook, Wilkinson, p. 752. Blackwell, Oxford and Edinburg, 1968.

El-Gothamy Zenab, Abdel-Fattah A. Ghaly A. F. : Tinea versicolor hypopigmentation Histochemical and Therapeutic Studies. Int. J. Dermatol., 1975, 14, 510.

EL-Hifnawi H., El-Gothamy Zenab, Refai M. : Studies on pityriasis versicolor in Egypt II. Mykosen, 1971, 14, 483 .

GeoRg L. J. : In Opportunistic Pathogens by Prier J. E. and Friedman H. p. I94. University Park Press, Baltimora, London, Tokyo, 1974.

Gordon M. A. : The lipophilic mycoflora of the skin I. In vitro culture of Pityrosporum orbiculare, n. sp. Mycologia, 1951a, 43, 524-535.

Hildick-Smith G., Blanck H., Sarkany I. : Fungus Diseases and their treatment. p. 5. J. A. Churchill Ltd, 1964, London.

Ito K., TANAKA : Amino acid metabolism of fungi. Decomposition of L-Tyrosine by fungi. Dermatology Proceedings of the XIV International Congress p. 735. American Elsevier Publishing Co Inc., New York, 1972.

Kistiakovsky E. V. : Pityriasis versicolor and ultraviolet rays. Arch. Dermatol., Syph., 1927, 15, 685 .

Lewis G. M., Hopper M. F. : Pseudo-achromia of tinea versicolor Arch. Dermatol. Syph., 1936, 34, 850.

SAlkin Ira F., Gordon M. A. (Under publication) : Polymorphism of Malassezia furfur.

Wilson J. W., Plunket O. A. : The fungus diseases of Man, p. 252. Berkley CA, University of California Press, Berkley CA, 1970. 